\title{
PENGARUH KEPERCAYAAN DAN KEMUDAHAN TERHADAP KEPUTUSAN PEMBELIAN MENGGUNAKAN PINJAMAN ONLINE SHOPEE PAYLATER
}

\author{
Fanny Anggraeny Putri \\ Universitas Negeri Surabaya \\ fannyanggraeny2@gmail.com \\ Sri Setyo Iriani \\ Universitas Negeri Surabaya \\ srisetyo@unesa.ac.id
}

\begin{abstract}
This financial technology innovation continues to develop along with changes in people's lifestyles. Financial services that provide online loan facilities are currently trending as a means of payment for several large $e$ commerce in Indonesia. Shopee is e-commerce that has a PayLater facility as an alternative method of shopping transactions that provides loan funds under the name Shopee PayLater. The use of Shopee PayLater makes it easy for consumers to shop online through the Shopee marketplace even though they don't have enough funds to shop. This research is a quantitative study with a conclusive research design to determine the effect of trust and ease on purchasing decisions using online loans. Sampling technique on this research used judgmental sampling and snowball sampling with a sample size of 110 respondents that Shopee users. Which are Shopee users have once made transactions using ShopeePayLater. The results of this study indicate there is a significant positive influence between trust and ease of purchasing decisions using online loans. Based on the result, it is recommended that Shopee PayLater make pay attention and make sure that this application has guaranteed security, so it can build a good image to increase the trust and have an impact to purchase decisions towards online loans Shopee PayLater.
\end{abstract}

Keywords: ease; online loan; purchase decision; trust.

\section{PENDAHULUAN}

Inovasi teknologi finansial dimulai dari dunia perbankan dengan munculnya Core Banking System (CBS), aplikasi yang merupakan jantung dari system perbankan. Merujuk kepada suatu fenomena keadaan di mana teknologi dan keuangan (finansial) beradu. Menurut Bank Indonesia (BI:2013) Financial technology/FinTech merupakan gabungan dari tekhnology yang beradu dengan sistem keuangan membentuk layanan keuangan baru berbasis teknologi. (bi.go.id, 2019).

Berbagai inisiatif produk dan layanan fintech muncul bersamaan dengan perubahan gaya hidup masyarakat yang serba online yang dirasa cepat dan mudah. Masyarakat didorong untuk bisa memenuhi kebutuhannya seperti berbelanja ini-itu hingga travelling ke sana-sini tanpa harus menunggu punya uang yang cukup, sebab ada fitur cicilan kartu kredit digital PayLater yang menjadi salah satu tren yang menarik perhatian milenial.(bi.go.id , 2019)

Riset DailySocial (2019) juga menunjukkan 51,9\% responden dari 347 orang mengatakan PayLater yang paling banyak digunakan sepanjang tahun ini adalah milik OVO PayLater. Selanjutnya pada posisi kedua diduduki oleh Gopaylater dan posisi ketiga adalah Shopee PayLater. Shopee merupakan e-commerce yang memiliki fasilitas PayLater sebagai alternatif metode pembayaran belanja dengan mencicil atau bayar lunas pada jatuh tempo pinjaman dengan menggandeng perusahaan peer to peer lending PT Lentera Dana Nusantara (LDN). Shopee menjadi e-commerce yang memperoleh jumlah frekuensi belanja tertinggi yakni sebesar $29 \%$. Sedangkan Tokopedia berada di peringkat dua dan disusul Lazada. Namun Shopee juga berada pada urutan kedua di bawah Tokopedia dari segi jumah pengunjung walaupun frekuensi belanja Shopee lebih tinggi dibanding Tokopedia (shopee.id ,2019).

Menurut iprice (2019), e-commers dengan pengunjung terbesar kuartal III tahun 2019 adalah marketplace Tokopedia yang disusul oleh Shopee. Jumlah pengunjung dari Tokopedia ini lebih banyak dibandingkan jumlah pengunjung dari marketplace Shopee. Diketahui Tokopedia memiliki jumlah pengunjung sebesar 66 juta penngunjung dan Shopee berada di bawahnya dengan 56 juta 
pengunjung. Sehingga dapat diketahui bahwa konsumen memiliki karakteristik atau kriteria yang berbeda-beda. Dari banyaknya kriteria konsumen, pengguna marketplace terbanyak adalah generasi millenial yang disusul generasi Z. (economy.okezone.com, 2019). Selain itu riset JakPat Mobile Survey dan Brilio.net terhadap 1.021 millenial usia 21-37 tahun di 34 kota besar Indonesia menunjukkan generasi ini lebih menyukai transaksi nontunai menggunakan kartu debit (50\%), uang elektronik alias e-money (33\%), dan kartu kredit (17\%). (faspay.co.id, 2019).

Hal tersebut menunjukkan bahwa keinginan masyarakat melakukan berbelanja menggunakan Sistem bayar nanti atau PayLater masih di bawah keputusan bertransaksi menggunakan kartu debit atau transfer ATM meskipun PayLater lebih mudah digunakan.

Tabel 1.

PERBANDINGAN LAYANAN PAYLATER

\begin{tabular}{|c|c|c|c|}
\hline Pembanding & GoPaylater & OVO Paylater & Shopee PayLater \\
\hline Syarat pengguna & $\begin{array}{l}\text { Meng-upgrade akun } \\
\text { Gojek }\end{array}$ & Terpilih & $\begin{array}{c}\text { Minimal } 3 \text { kali transaksi } \\
\text { belanja }\end{array}$ \\
\hline Saldo limit awal & Rp500.000,- & Rp1.000.000,- & $\begin{array}{c}\mathrm{Rp} 450.000- \\
\mathrm{Rp} 1.800 .000\end{array}$ \\
\hline Tanggal Pengembalian & Sebelum tanggal 1 & Sebelum tanggal 1 & Sebelum tanggal 5 \\
\hline Bunga pinjaman & $0-12 \%$ per bulan & $0-2,90 \%$ per bulan & $0-2,95 \%$ per bulan \\
\hline Cara aktifkan & Gojek & Tokopedia & Shopee \\
\hline Penggunaan Fasilitas & $\begin{array}{l}\text { Go-ride, Go-car, Go- } \\
\text { bills, Go-tix dan } \\
\text { Go-Shop. }\end{array}$ & $\begin{array}{c}\text { Belanja melalui } \\
\text { marketplace } \\
\text { Tokopedia }\end{array}$ & $\begin{array}{c}\text { Belanja melalui } \\
\text { marketplace Shopee }\end{array}$ \\
\hline
\end{tabular}

Sumber: ovoint.com (2018); shopee.id (2018); gojek.com (2018), data diolah.

Tabel 1 menunjukkan perbandingan layanan dari Paylater yang paling banyak digunakan Dari tabel tersebut dapat diketahui bahwa Shopee PayLater lebih mudah diaplikasikan dari sisi cara mengaktifkan, jumlah limit pinjaman yang diberikan lebih banyak dan jangka waktu pinjaman yang diberikan lebih lama. Hal tersebut sesuai menurut Davis (1989) kemudahan (ease) bermakna tanpa kesulitan atau tidak memerlukan usaha keras saat menggunakan teknologi tersebut. Didukung dengan penelitian Andy Putra Mahkota, Imam Suyadi , Riyadi (2014) dan penelitian Lita Limpo,Meryana (2015) yang juga mengatakan bahwa kemudahan berpengaruh signifikan terhadap keputusan pembelian secara online.

Namun hasil Riset Daily Social Shopee PayLater berada di urutan ketiga di bawah GoPaylater dan OVO Paylater meskipun Shopee PayLater lebih mudah diaplikasikan. Hal tersebut menjadi bertolak belakang dan mendukung penelitian Desthri Annisa (2019) yang mengatakan jika tidak dipengaruhi variabel lain, maka variabel kemudahan tidak berpengaruh terhadap keputusan pembelian secara online melalui aplikasi Shopee.

Sedangkan menurut Davis (1989) perspektif kemudahan pengaplikasian (perceived ease of use) merupakan sebuah tingkat kepercayaan seseorang bahwa jika seseorang menggunakan sistem tersebut maka usaha yang dikeluarkan untuk mengerjakan sesuatu akan berkurang., maka hal ini sesuai dengan Barnes, Chen (2007) Kepercayaan adalah elemen penting yang memengaruhi perilaku konsumen. Sehingga mendukung Pavlou (2014) bahwa kepercayaan (trust) menjadi dasar bagi konsumen menaruh harapan terhadap hubungan tukar menukar atau melakukan transaksi.

Dari tabel 1 dapat diketahui jumlah pengunjung marketplace Shopee sebanyak 56 juta pengunjung, hal tersebut menunjukkan banyak konsumen percaya dengan aplikasi tersebut. Sehingga mendukung penelitian Anggraeni dan Madiawati (2016) bahwa jika tanpa pengaruh variabel lain, maka kepercayaan berpengaruh terhadap keputusan pembelian melalui situs traveloka.com. Istianti (2017) juga mengatakan bahwa terdapat pengaruh positif kepercayaan terhadap keputusan pembelian secara online di kota Surabaya. 
Fanny Anggraeny Putri \& Sri Setyo Iriani. Pengaruh Kepercayaan dan Kemudahan terhadap Keputusan Pembelian Menggunakan Pinjaman Online Shopee Paylater

Namun hal tersebut menjadi bertolak belakang ketika Shopee masih berada pada urutan kedua di bawah Tokopedia mengingat Shopee memiliki layanan pinjaman online Shopee Paylater yang memudahkan konsumen dibandingkan OVO Paylater dari Tokopedia. Ini mendukung penelitian Wardoyo dan Andini (2017) bahwa jika tanpa pengaruh variabel lain, maka kepercayaan tidak berpengaruh terhadap keputusan pembelian online.

Penelitian ini bertujuan untuk menganalisis pengaruh kepercayaan dan kemudahan terhadap keputusan pembelian menggunakan pinjaman online.

\section{KAJIAN PUSTAKA DAN PENGEMBANGAN HIPOTESIS}

\section{Kepercayaan}

Kepercayaan menjadi faktor konsumen dalam memutuskan untuk melakukan pembelian suatu produk secara online. (Turban, 2015:408) Hal ini disebabkan tidak adanya tatap muka antara pedagang dengan pembeli atau konsumen. Menurut Barnes, Chen (2007) Kepercayaan adalah elemen penting yang memengaruhi perilaku konsumen. Turban dan Lee (2015:413) menyebutkan tingkat kepercayaan ditentukan oleh tiga kategori utama faktor, yaitu kepercayaan pedagang internet, saluran belanja, dan jaminan struktural terkait dengan bisnis dan peraturan lingkungan sekitar. Mayer et al., dalam Pennington, et.al (2003) mendefinisikan trust yaitu kesediaan suatu pihak untuk berhubungan dengan pihak lain dengan harapan pihak lain akan melakukan tindakan yang menguntungkan bagi pemberi kepercayaan. Sedangkan menurut Gefen (2002) yang mengacu pada penelitian sebelumnya bersama Mayer mengatakan kepercayaan dapat dipercaya melalui kemampuan, integritas dan kebaikan hati yang digunakan secara bergantian. Sehingga indikator kepercayaan dalam penelitian ini mengacu pada Mayer et al., 1995 (dalam Ardyanto 2016), Gefen (2002), Robbins dan Judge (2007) dalam Anggraeny (2016) yaitu Kemampuan (ability), Kebaikan Hati (benevolence) dan Integritas (integrity).

\section{Kemudahan}

Kemudahan menjadi pengaruh bagi konsumen dalam memutuskan melakukan transaksi pembelian.(Davis, 1989) Perubahan zaman yang serba instan dan mudah turut mengubah pola gaya hidup masyarakat menjadi serba cepat. Berdasarkan teori Technology Acceptance Model (TAM) dalam Mohd. Yusoff (2011), TAM berpendapat bahwa persepsi kemudahan penggunaan adalah faktor penting yang menentukan sikap pengguna terhadap niatnya untuk menggunakan. Menurut Davis (1989) perspektif kemudahan pengaplikasian (perceived ease of use) merupakan sebuah tingkat kepercayaan seseorang bahwa jika seseorang menggunakan sistem tersebut maka usaha yang dikeluarkan untuk mengerjakan sesuatu akan berkurang. Sedangkan menurut Pavlou (2014) Kemudahan yang diterapkan pada perilaku konsumen on-line, antarmuka Web yang dianggap memfasilitasi proses transaksi dan mudah dioperasikan kemungkinan akan diterima oleh konsumen. Sehingga indikator dalam penelitian ini mengintegrasikan pendapat Priyono, et al.(2016), Davis et al, dalam Ratnawati (2018) Venkatesh dan Davis, 2000 (dalam Ardyanto, 2016) membentuk indikator yaitu Interaksi individu dengan sistem jelas dan mudah dimengerti (clear and understandable), Tidak dibutuhkan banyak usaha untuk berinteraksi dengan sistem tersebut (does not require a lot of mental effort), Sistem mudah digunakan (easy to use) dan mudah mengoperasikan sistem sesuai dengan apa yang ingin individu kerjakan (easy to get the system to do what he/she wants to do).

\section{Keputusan Pembelian}

Keputusan pembelian dalam jaringan adalah proses pembelian oleh konsumen menggunakan media internet yang memiliki nilai manfaat yang lebih tinggi Deavaj et al, dalam Anggraeni (2016). Menurut Iswara (2016) keputusan pembelian ialah perilaku konsumen terkait jadi atau tidaknya melakukan suatu pembelian atau transaksi. Menurut Kotler dan Armstong, dalam Wardoyo (2017) menjelaskan bahwa keputusan pembelian merupakan tindakan atau perilaku seseorang dalam melakukan keputusan untuk memilih suatu produk baik dari sisi jenis maupun kuantitas produk itu sendiri.

Selain itu menurut Andrade et al, dalam Zhang dan Li (2002) mengatakan pembelian online sangat terikat dengan karakteristik penjual dan pembeli, karakteristik layanan atau produk yang diberikan, situs web, sikap dan niat serta keputusan dalam berbelanja online. Indikator variabel keputusan 
pembelian online pada penelitian Devaraj et al, (2003) dan Khairani (2015) dalam Lestari (2018) yaitu keputusan tentang reputasi vendor, keputusan tentang prioritas pembelian, keputusan tentang efisiensi pencarian, dan keputusan tentang frekuensi transaksi.

\section{Hubungan antar Variabel}

Maraknya teknologi berbasis online menjadikan kepercayaan sebagai dasar konsumen dalam menentukan keputusan pembelian. (Harahap dan Amanah, 2018) Dilihat dari sisi ketidak bertemuan antara pedagang dengan calon konsumen, menjadikan kepercayaan menjadi faktor penentu konsumen dalam melakukan keputusan pembelian. Penelitian yang dilakukan oleh Jia Shen (2018) memiliki hasil bahwa kepercayaan (trust) berpengaruh signifikan positif terhadap keputusan pembelian sebuah produk. Sedangkan penelitian yang dilakukan oleh Andy Putra Mahkota, Imam Suyadi , Riyadi (2014) juga mengatakan bahwa kepercayaan berpengaruh secara significant terhadap keputusan pembelian secara online. Kepercayaan menjadi kunci bagi penjual dan pembeli melakukan transaksi dengan media online. Hanya pelanggan yang memiliki kepercayaan yang akan melalui transaksi melalui internet.

\section{H1: Ada pengaruh kepercayaan terhadap keputusan pembelian menggunakan pinjaman online.}

Kemudahan (ease of use) menurut Davis dalam Andini, Wardoyo (2017) mendefinisikan percieved ease of use sebagai keyakinan akan kemudahan penggunaan. Frekwensi penggunaan dan interaksi antara pengguna (user) dengan sistem juga mampu menunjukan kemudahan penggunaan. Sistem yang lebih sering digunakan menunjukan bahwa sistem tersebut lebih dikenal, lebih mudah dioperasikan dan lebih mudah digunakan oleh penggunanya. Penelitian yang dilakukan oleh Lestari dan Iriani (2018) tentang Pengaruh Kepercayaan Dan Kemudahan Transaksi Terhadap Keputusan Pembelian Secara Online Pada Situs Mataharimall.Com menunjukkan Kemudahan Transaksi menjadi variabel paling dominan dan berpengaruh secara signifikan terhadap keputusan bertransaksi pada situs Mataharimall.com. Selain itu menurut Danu Iswara (2016) juga mengatakan bahwa terdapat pengaruh positif antara kemudahan dengan keputusan pembelian melalui media social. Hubungan antar variabel juga digambarkan di Gambar 1.

H2 : Ada pengaruh kemudahan terhadap keputusan pembelian menggunakan pinjaman online.

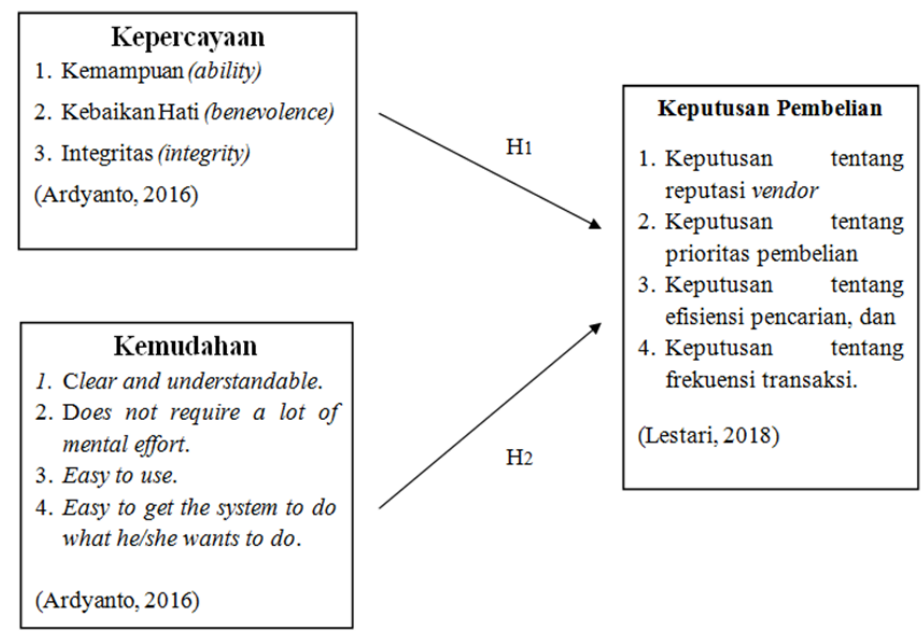

Gambar 1 MODEL PENELITIAN

\section{METODE PENELITIAN}

Jenis penelitian ini adalah penelitian kuantitatif dengan metode survey dengan rancangan penelitian menggunakan pendekatan kausal. Data yang digunakan dalam penelitian ini adalah data primer dan data sekunder menggunakan angket dan wawancara secara chatting. Variabel bebas yang terdapat pada penelitian ini adalah kepercayaan dan kemudahan. Sedangkan variabel terikat dalam penelitian ini adalah keputusan pembelian. Populasi yang menjadi sasaran adalah pengguna marketplace Shopee 
Fanny Anggraeny Putri \& Sri Setyo Iriani. Pengaruh Kepercayaan dan Kemudahan terhadap Keputusan Pembelian Menggunakan Pinjaman Online Shopee Paylater

dengan kriteria pernah melakukan transaksi sebanyak 3 kali transaksi dan pernah berbelanja menggunakan Shopee PayLater sebanyak satu kali transaksi. Jumlah sampel penelitian ini adalah 110 orang, yang mana jumlah sampel adalah jumlah indikator dikali lima sampai sepuluh (Sujadmika, 2017). Dalam penelitian ini terdapat 11 buah indikator penelitian. Maka, jumlah minimal anggota sampel adalah 5-110 responden. Teknik pengumpulan data yang digunakan adalah angket kuesioner yang didistribusikan secara online melalui Google Form yang disebar melalui media sosial komunitas pengguna Shopee pada Whatsapp group, Facebook dan Instagram.

Teknik pengambilan sampel yang digunakan oleh peneliti adalah purposive sampling, di mana teknik yang digunakan adalah judgemental sampling dan snowball sampling yang dipilih dari responden awal (Malhotra,2009). Kemudian dilakukan uji validitas dan reliabilitas terhadap instrumen penelitian yang akan digunakan sebanyak 30 responden (Ghozali, 2016). Setelah lolos uji ini, maka selanjutnya akan disebar untuk memperoleh 110 responden yang selanjutnya di uji validitas dan reliabilitas kembali, setelah itu dilakukan uji asumsi klasik dan memenuhi model regresi linier berganda. Data yang terkumpul dianalisis dengan regresi linier berganda dengan menggunakan uji asumsi klasik yaitu uji normalitas, uji multikolinieritas dan uji heterokedastisitas. Selanjutnya, data akan diproses dengan uji hipotesis dengan menggunakan Uji t dan uji koefisien determinasi.

\section{HASIL DAN PEMBAHASAN}

\section{Karakteristik Responden}

Deskripsi karakteristik responden pada penelitian ini berdasarkan demografi jeniskelamin, pekerjaan dan usia pada konsumen Shopee. Tabel 2 meunjukkan karakteristik responden pada penelitian ini. Dari hasil tabel 2 menunjukkan bahwa responden pada penelitian ini didominasi oleh perempuan dengan pekerjaan sebagai mahasiswa atau pelajar yang rentang usia nya 17-26 tahun. Hal tersebut disebabkan pengguna marketplace adalah kebanyakan generasi Y dan Z. Selain itu mahasiswa atau pelajar khususnya perempuan memang sangat menyukai sistem belanja secara online yang dirasanya lebih mudah daripada harus keluar ke toko untuk memperoleh barang yang diinginkan.

\section{Tabel 2.}

\section{KARAKTERISTIK RESPONDEN}

\begin{tabular}{clcc}
\hline \multicolumn{2}{c}{ Karakteristik Responden } & Jumlah & Presentase (\%) \\
\hline \multirow{3}{*}{ Jenis Kelamin } & Laki-Laki & 38 & $34,5 \%$ \\
& Perempuan & 72 & $65,5 \%$ \\
& PNS & 1 & $0,9 \%$ \\
& Wirausaha & 6 & $5,5 \%$ \\
Pekerjaan/Status & Mahasiswa/Pelajar & 81 & $73,6 \%$ \\
& Pegawai Swasta & 16 & $14,5 \%$ \\
& Lainnya & 6 & $5,5 \%$ \\
\multirow{4}{*}{ Usia } & 17-26 Tahun & 103 & $93,6 \%$ \\
& 27-36 Tahun & 5 & $4,6 \%$ \\
& 47-41 Tahun & 0 & $0 \%$ \\
& 42-51 Tahun & 2 & $1,8 \%$ \\
& 52-65 Tahun & 0 & $0 \%$ \\
\hline \multirow{6}{*}{ Sum } & 110 & $100 \%$ \\
\hline
\end{tabular}

Sumber: diolah peneliti

\section{Hasil Uji Asumsi Klasik}

Sebelum melakukan uji regresi untuk memperoleh hasil maka dilakukan uji asumsi klasik untuk mengetahui kepastian ketepatan persamaan regresi. Hasil uji normalitas data menggunakan OneSample Kolmogorov-Smirnov Test diperoleh hasil nilai signifikansi Asymp. Sig. (2-tailed) sebesar 0,186 lebih besar dari 0,05. Maka sesuai dasar pengambilan keputusan dalam uji normalitas, data 
tersebut berdistribusi normal. Hasil Uji Multikolinieritas diperoleh nilai VIF dari variabel kepercayaan yaitu $3.824 \leq 10$. Nilai VIF dari variabel kemudahan yaitu $3.824 \leq 10$. Artinya tidak terjadi multikolonieritas antar variabel independent. Hasil Uji Heteroskedastisitas menggunakan grafik Scatterplot dapat dilihat di gambar 2. Gambar 2 menunjukkan menunjukkan bahwa titik titik tidak membentuk pola sehingga data penelitian ini tidak terjadi gejala Heteroskedastisitas.

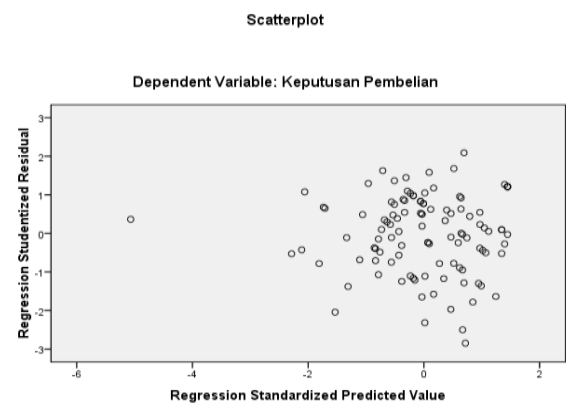

Sumber: Output SPSS Windows 16

\section{Gambar 2. GRAFIK SCATTERPLOT UJI HETEROSKEDASTISITAS}

\section{Hasil Uji Regresi Linier Berganda}

Setelah memperoleh hasil uji asumsi klasik yang sesuai maka selanjutnya dilakukan uji regresi linier berganda. Uji regresi linier berganda menggunakan SPSS 16.0 for windows memperoleh hasil yang dapat dilihat di tabel 3. Dari tabel tersebut diperoleh persamaan regresi linear berganda (1).

$Y^{\prime}=-0,323+0,195 \mathrm{X} 1+0,482 \mathrm{X} 2$

\section{Tabel 3.}

HASIL UJI REGRESI LINIER BERGANDA

\begin{tabular}{cccc}
\hline Model & \multicolumn{2}{c}{ Unstandardized Coefficient } & sig \\
& $\mathbf{B}$ & $-0,151$ &, 880 \\
\hline Konstanta & $-0,323$ & 1,989 &, 049 \\
Kepercayaan &, 195 & 4,472 &, 000 \\
Kemudahan &, 482 &
\end{tabular}

Sumber: Output SPSS 16 for Windows

Sehingga dari hasil tersebut dapat diinterpretasikan bahwa nilai koefisien kepercayaan sebesar 0,195 menunjukan jika kepercayaan seseorang menggunakan pinjaman online Shopee PayLater tinggi maka semakin yakin pula seseorang untuk melakukan transaksi menggunakan Shopee PayLater melalui Shopee. Dan nilai koefisien kemudahan sebesar 0,482 menunjukkan bahwa semakin mudah Shopee PayLater dalam memberikan layanan pinjaman maka semakin tinggi frekuensi transaksi menggunakan Shopee PayLater. Nilai konstanta adalah -0,323 dapat diartikan bahwa tanda negatif pada konstanta menunjukkan apabila tidak terdapat kepercayaan dan kemudahan maka keputusan pembelian tidak akan terjadi. Sehingga jika seseorang tidak percaya dan merasa mudah dalam menggunakan platform tertentu maka keputusan untuk melakukan pembelian melalui platform tersebut tidak akan terjadi.

\section{Hasil Uji Kelayakan Model}

Dari hasil uji kelayakan model memperoleh nilai Adjusted R Square penelitian ini sebesar $0.576=$ $57,6 \%$. Nilai tersebut menunjukkan bahwa kepercayaan (X1) dan kemudahan (X2) terhadap variabel terikat keputusan pembelian menggunakan Shopee PayLater sebesar 0.576 atau 57,6\%. Sedangkan sisanya $42,4 \%$, menunjukkan sebesar $42,4 \%$ penelitian ini dipengaruhi oleh variabel selain kepercayaan dan kemudahan.

\section{Hasil Uji Hipotesis (Uji t)}


Berdasarkan tabel 3, dapat dijelaskan bahwa hasil uji t diperoleh nilai t hitung variabel kepercayaan (X1) adalah sebesar 1.989 dengan nilai signifikan sebesar 0,049 yang lebih kecil dari 0,05 atau 5\%, sehingga $\mathrm{H}_{0}$ ditolak dan $\mathrm{H} 1$ diterima. Oleh karena itu, pada penelitian ini menunjukkan terdapat pengaruh positif antara kepercayaan terhadap keputusan pembelian menggunakan pinjaman online. Selanjutnya untuk untuk variabel kemudahan (X2) memperoleh nilai t-hitung sebesar 4.472 dan didukung dengan nilai signifikan sebesar 0,000 yang lebih kecil dari 0,05 atau $5 \%$, maka $\mathrm{H}_{0}$ ditolak dan H1 diterima. Sehingga dapat dikatakan bahwa terdapat pengaruh positif antara kemudahan terhadap keputusan pembelian menggunakan pinjaman online. Berdasarkan hasil tersebut nilai thitung variabel kemudahan lebih besar dibandingkan varibel kepercayaan, maka dapat dikatakan konsumen tertarik menggunakan layanan pinjaman online pada marketplace karena memudahkan belanja meskipun belum memiliki biaya yang cukup untuk berbelanja.

\section{Pengaruh Kepercayaan (X1) terhadap Keputusan Pembelian (Y)}

Dari hasil penelitian ini menunjukkan bahwa nilai koefisien variabel Kepercayaan adalah positif (+) yang berarti adanya pengaruh positif dan signifikan antara kepercayaan (X1) dengan keputusan pembelian (Y) pengguna pinjaman online Shopee PayLater, artinya semakin seseorang percaya pada Shopee PayLater maka semakin yakin keputusan orang tersebut untuk bertransaksi menggunakan Shopee PayLater. Hal ini sesuai dengan fenomena sekarang yang marak terjadi penipuan dalam penggunaan transaksi belanja secara online khususnya menggunakan pinjaman online. Sehingga apabila seseorang tidak percaya pada suatu platform maka tidak akan terjadi keputusan pembelian.

Hasil bahwa terdapat pengaruh yang signifikan antara kepercayaan terhadap keputusan pembelian menggunakan pinjaman online pada penelitian ini mendukung penelitian sebelumnya yang dilakukan oleh Lita,Meryana (2015), Mahkota et al, (2014), Anggraeni, Madiawati (2016) dan Lestari, Iriani (2018).

Kepercayaan Shopee merupakan tercerminnya kesediaan konsumen untuk menggunakan marketplace Shopee. Banyaknya pengunjung dan pengguna Shopee menjadikan marketplace ini menjadi $e$ commers dengan jumlah frekuensi belanja tertinggi dan jumlah pengunjung terbanyak kedua setelah Tokopedia menurut riset iprice kuartal ke-tiga tahun 2019. Fasilitas sistem pembayaran Shopee PayLater juga telah terdaftar dan diawasi oleh OJK sehingga terjamin keamanan transaksinya. Hal tersebut juga dapat membangun kepercayaan pelanggan terhadap Shopee PayLater dari Shopee ini.

Dalam penelitian ini responden perempuan sebagai responden yang mendominasi dengan rentang usia terbanyak adalah 17-26 tahun yang merupakan mahasiswa/pelajar dan kategori produkyang sering dibeli adalah fashion. Selain itu hasil tertinggi dari pernyataan item kepercayaan terletak pada indikator integritas (integrity) yaitu "Kode konfirmasi pembayaran konsumen melalui Shopee PayLater bersifat rahasia". Hal ini disebabkan mahasiswa/pelajar khususnya perempuan sangat senang apabila mendapat pinjaman uang untuk berbelanja sehingga dapat tetap berbelanja dan tetap tampil trendy dengan fashion-fashion terbaru meskipun belum memiliki cukup biaya. Selain itu mahasiswa juga senang apabila media yang digunakan dapat dipercaya sehingga lebih yakin dalam melakukan transaksi belanja.

Terdapat implikasi teoritis yang dihasilkan dari penelitian ini. Penelitian ini mendukung kerangka teoritis keputusan pembelian bahwa variabel kepercayaan berpengaruh positif terhadap keputusan pembelian. Selain itu implikasi dari penelitian ini terhadap perusahaan atau pemasar yang dalam hal ini merupakan pembuat aplikasi adalah pertama, berdasarkan karakteristik responden, banyak didominasi oleh perempuan daripada laki-laki. Usia didominasi antara 17-26 tahun dengan status/pekerjaan sebagai pelajar/mahasiswa. Hal ini bermanfaat bagi pembuat aplikasi untuk lebih fokus dalam memperhatikan konsumen potensial sesuai hasil penelitian ini. Sehingga layanan yang diberikan tepat sasaran dan mampu meningkatkan kepercayaan konsumen untuk menggunakan Shopee PayLater. 
Dari hasil penelitian ini maka diperoleh nilai koefisien untuk variabel kemudahan bernilai positif yang menunjukkan bahwa pengaruh positif dan signifikan antara kemudahan (X1) dan keputusan pembelian (Y) pengguna pinjaman online Shopee PayLater. Selain itu nilai t-hitung kemudahan lebih besar dibandingkan kepercayaan yang menunjukkan bahwa kemudahan lebih mempengaruhi keputusan pembelian pada penelitian ini. Hal ini menunjukkan bahwa seseorang tidak akan menggunakan sistem yang rumit mengingat fenomena sekarang yang serba cepat dan mudah dalam memperoleh sesuatu. Hal tersebut juga mendukung penelitian terdahulu yang dilakukan oleh Lita, Meryana (2015), Istianti (2017), Lestari,Iriani (2018), Mohd. Yusoff et al, dan Ramayah, Ignatius (2005).

Shopee memberikan kemudahan dengan menawarkan berbelanja beli sekarang bayar nanti menggunakan Shopee PayLater. Selain itu kemudahan dalam proses pengajuan kredit juga mudah yang hanya menggunakan foto diri dan foto Kartu Tanda Penduduk (KTP). Dalam penelitian ini yang mendominasi adalah responden perempuan dengan usia 17-26 tahun. Hal tersebut sesuai dengan riset Jackpat Mobile Survey bahwasanya generasi usia antara 17-26 tahun adalah generasi yang menyukai sistem pembayaran non-tunai atau menggunakan fintech. Sehingga hal tersebut sesuai mengingat mahasiswa atau pelajar khususnya perempuan menyukai hal-hal yang instan, mudah dan tidak rumit. Selain itu hasil tertinggi dari pernyataan item kemudahan terletak pada indikator easy to get the system to do what he/she wants to do yaitu "Shopee PayLater mempermudah belanja sesuai kebutuhan konsumen". Hal ini disebabkan mahasiswa tidak suka dengan hal-hal yang rumit jika membutuhkan sesuatu. Sehingga lebih senang apabila apa yang dibutuhkan cepat terpenuhi.

Implikasi teoritis yang dihasilkan adalah penelitian ini mendukung kerangka teoritis keputusan pembelian bahwa variabel kemudahan juga berpengaruh positif terhadap keputusan pembelian. Selain itu implikasi dari penelitian ini terhadap perusahaan atau pemasar yang dalam hal ini merupakan pembuat aplikasi berdasarkan karakteristik responden yang banyak menggunakan Shopee PayLater adalah perempuan daripada laki-laki dengan rentang usia 17-26 tahun yang sangat memperhatikan keamanan layanan dalam melakukkan transaksi secara online. Dari hal tersebut keamanan pengguna transaksi perlu diperhatikan agar lebih dapat membangun image positif perusahaan sehingga konsumen lebih percaya dalam menggunakan aplikasi ini. Kemudian pembuat aplikasi juga disarankan untuk meningkatkan kualitas layanan yang diberikan untuk lebih memudahkan konsumen dalam melakukan transaksi sehingga meningkatkan ketertarikan konsumen untuk melakukan transaksi secara berulang.

\section{KESIMPULAN}

Dari hasil penelitian maka diperoleh kesimpulan sebagai berikut. Terdapat pengaruh positif variabel kepercayaan terhadap keputusan pembelian menggunakan pinjaman online. Terdapat pengaruh positif antara variabel kemudahan terhadap keputusan pembelian menggunakan pinjaman online. Variabel kemudahan lebih dominan dibandingkan variabel kepercayaan dalam mempengaruhi keputusan pembelian menggunakan pinjaman online.

Penelitian ini tentunya memiliki keterbatasan di antaranya adalah sebagai berikut. Penelitian ini tidak menggunakan variabel moderasi seperti corporate image sebagai penguat kepercayaan sebelum melakukan keputusan pembelian. Cara pengumpulan data hanya menggunakan angket online. Penelitian ini tidak menyediakan angket terbuka terkait kepercayaan dan kemudahan sehingga pembahasan yang diberikan kurang mendalam. Sehingga dari hal tersebut disarankan untuk penelitian selanjutnya menambahkan variabel moderasi seperti corporate image atau percieved usefulness untuk memperkuat kepercayaan dan kemudahan terhadap keputusan pembelian menggunakan pinjaman online. Selain itu, angket terbuka dapat mengeksplor jawaban lebih detail lagi.

\section{DAFTAR PUSTAKA}

Andryanto, R. (2016). Pengaruh Kepercayaan, Persepsi Manfaat, Dan Persepsi Kemudahan Penggunaan Terhadap Minat Beli Di Toko Online (Studi Empiris yang dilakukan pada OLX.co.id di Yogyakarta). 
Fanny Anggraeny Putri \& Sri Setyo Iriani. Pengaruh Kepercayaan dan Kemudahan terhadap Keputusan Pembelian Menggunakan Pinjaman Online Shopee Paylater

Anggraeni, P., \& Madiawati, P. N. (2016). The Efect Of Trust And Information Quality To Online Purchase Decision On The Site Www.Traveloka.Com Penia.E-Proceeding of Management :, 3(2), 1880-1887.

Annisa, D. (2015). Pengaruh Kepercayaan, Kemudahan Dan Kualitas Informasi Terhadap Keputusan Pembelian Online Melalui Aplikasi Shopee (Studi Kasus Pada Mahasiswa Ilmu Komunikasi Universitas Mulawarman 2015 - 2017). 23(2), 112-120.

Ayu Lestari, N. (2018). Pengaruh Kepercayaan Dan Kemudahan Transaksi Terhadap Keputusan Pembelian Secara Online Pada Situs Mataharimall.Com. Jurnal Ilmu Manajemen (JIM), 6(1), $1-8$.

BI.go.id. (2019). Instrumen Pembayaran Non-Tunai (https://www.bi.go.id/id/sistempembayaran/instrumen-nontunai/unik/Contents/Default.asp diakses pada 13 Desember 2019).

Cekindo.com, (2019). Perkembangan Teknologi Finansial (Fintech) di Indonesia.(https://www.cekindo.com/id/group1-id/perkembangan-teknologi-finansial-fintechdi-indonesia diakses pada 13 November 2019)

Dailysocial.id, (2019). (https://dailysocial.id/post/shopee-paylater diakses pada 25 November 2019)

Davis,F.D. 1989. "Perceived Usefulness, Perceived Ease of Use, and User Acceptance of Information Technology". MIS Quarterly.Vol. 13 No. 5: pp319-339.

Faspay.co.id. (2018). 3 Jenis Pembayaran Cashless Ini Lebih Disukai Millennials (https://www.faspay.co.id/2018/02/28/3-jenis-pembayaran-cashless-ini-lebih-disukaimillennials/ diakses pada 25 Januari 2020)

Gefen, David. (2002). "Reflection on the dimensions of trust and trustworthiness among online consumers". Database3 for advances in information. New York

Ghozali, Imam. 2016. Aplikasi Analisis Multivariete Dengan Program IBM SPSS 23 (Edisi 8). Cetakan ke VIII. Semarang: Badan Penerbit Universitas Diponegoro.

Hadijah S. (2019) Aplikasi Layanan Pay Later Makin Diminati, Yuk Cek Keuntungan dan Kerugiannya. (https://www.cermati.com/artikel/aplikasi-layanan-pay-later-makin-diminati-yukcek-keuntungan-dan-kerugiannya diakses pada 13 November 2019)

Harahap, D. A. (2018). Perilaku Belanja Online Di Indonesia: Studi Kasus. JRMSI - Jurnal Riset Manajemen Sains Indonesia, 9(2), 193-213. https://doi.org/10.21009/jrmsi.009.2.02

Istanti Fredianaika, issn: 2355-8869 dan E. 2356-2544. (2017). Pengaruh Harga, Kepercayaan, Kemudahan Berbelanja dan E-promosi Terhadap Keputusan Pembelian Belanja Online di Kota Surabaya. Jurnal Bisnis \& Teknologi Politeknik, 4(1), 14-22.

Iswara, D. (2016). Pengaruh Kepercayaan, Kemudahan, Kualitas Informasi Dan Persepsi Resiko Terhadap Keputusan Pembelian. IOSR Journal of Economics and Finance, 3(1), 1-217. https://doi.org/https://doi.org/10.3929/ethz-b-000238666

Kotler, Philip \& Kevin Lane Keller. 2009, Manajemen Pemasaran Edisi 13 Jilid 2. Penerbit Erlangga: Jakarta.

Li, N. and Zhang, P. (2002), "Consumer online shopping attitudes and behavior: an assessment of research.

Liang, T. P., \& Lai, H. J. (2002). Effect of store design on consumer purchases: Van empirical study of on-line bookstores. Information and Management,39, 431-444. 
Limpo, L., \& Meryana. (2017). Effect of Trust and Easy on Decision Online Purchase toward Special Fashion Products. International Journal of Science and Research (IJSR), 6(10), 715-717. https://doi.org/10.21275/ART20177118

Mahkota, A. P. (2014). Pengaruh Kepercayaan Dan Kenyamanan Terhadap Keputusan Pembelian Online (Studi Pada Pelanggan Website Ride Inc). Jurnal Administrasi Bisnis, 8(2).

Malhotra, N.K., 2009, Riset Pemasaran, Edisi keempat, Jilid 1, PT Indeks, Jakarta

Mohd.Yusoff, Y., Muhammad, Z., Mohd Zahari, M. S., Pasah, E. S., \& Robert, E. (2009). Individual Differences, Perceived Ease of Use, and Perceived Usefulness in the E-Library Usage. Computer and Information Science, 2(1), 2-9. https://doi.org/10.5539/cis.v2n1p76

Nawangsari, S \& Karmayanti (2018) Pengaruh Kepercayaan, Kemudahan, Dan Kualitas Informasi Terhadap Keputusan Pembelian Melalui Media Sosial Instagram (Studi Kasus Pada Online Shop YLK.Store). Konferensi Nasional Sistem Informasi 2018 STMIK Atma Luhur Pangkalpinang, 8 - 9 Maret 2018

NERACA, Berita Terkini Ekonomi Indonesia (2018). Riset: Shopee, Lazada, dan Tokopedia Brand yang Paling Diingat. (https://economy.okezone.com/read/2018/03/26/320/1878025/risetshopee-lazada-dan-tokopedia-brand-yang-paling-diingat diakses pada 11 November 2019)

Pavlou, P. A. (2003). Consumer Acceptance of Electronic Commerce: Integrating Trust and Risk with the Technology Acceptance Model. International Journal of Electronic Commerce, 7 (3), 69103.

Priyono, A Agus ;Hidayat, Ismail ; Arifin, R. (2017). PengaruhKepercayaan, Kemudahan, Harga Dan KualitasInformasiPenggunaan E-CommeceTerhadap Keputusan PembelianSecaraOnline Pada Situs Bukalapak.Com. E-JurnalRisetManajemen Prodi ManajemenFakultasEkonomiUnisma, 6(3), 64-78.

R.Pennington., H. Dixon, Grover, V. (2003). The Role of System Trust in Business-to-Consumer Transactions. Pages 197-226. https://doi.org/10.1080/07421222.2003.11045777

Ramayah, T., \& Ignatius, J. (2005). Impact of Perceived usefulness, Perceived ease of use and Perceived Enjoyment on Intention to Shop Online. ICFAI Journal of Systems Management (IJSM), 1-16. Retrieved from http://ramayah.com/journalarticlespdf/impactpesu.pdf

Riely M, Fajrian.(2019). Cetak Penjualan Rp 54 T, Shopee E-Commerce Terpopuler di Asia Tenggara. (https://katadata.co.id/berita/2019/08/23/cetak-penjualan-rp-54-t-shopee-e-commerceterpopuler-di-asia-tenggara diakses pada 25 Oktober 2019)

Setyowati D. (2019). Riset: Fitur Paylater OVO Paling Banyak Digunakan Tahun Ini (https://katadata.co.id/berita/2019/11/27/riset-fitur-paylater-ovo-paling-banyak-digunakantahun-ini diakses pada 10 Februari 2020)

Simamora. B., 2005, Riset pemasaran: Falsafah, teori, dan aplikasi, PT Gramedia Pustaka Utama, Jakarta

Sudjadmika, F. V. (2017). Pengaruh Harga, Ulasan Produk, Kemudahan, Dan Keamanan Terhadap Keputusan Pembelian Secara Online Di Tokopedia.Com. AGORA, Vol. 5, No. 1.

Suki, N. M. (2011). Exploring the relationship between perceived usefulness, perceived ease of use, perceived enjoyment, attitude and subscribers' intention towards using 3G mobile services. Journal of Information Technology Management, XXII(1), 1-7. 
Fanny Anggraeny Putri \& Sri Setyo Iriani. Pengaruh Kepercayaan dan Kemudahan terhadap Keputusan Pembelian Menggunakan Pinjaman Online Shopee Paylater

Sumarwan, Ujang. 2015. Pemasaran Strategik:Prespektif Perilaku Konsumen, dan Marketing Plan. Jakarta: PT.Ghalia Indonesia.

Turban. E., King. D., Lee. J. K., Liang, T. P., and Turban, D.C., (2015), Electronic Commerce: A Managerial and Social Networks Perspective. 8th Ed.

Wardoyo, \& Andini, I. (2017). Sosial Facebook Dalam Penerapan Strategi Promosi Penjualan Online Shop. Jurnal Manajemen Daya Saing, 19(1), 12-26. https://doi.org/10.23917/dayasaing.v19i1.5101 